THE ETHICAL ORGANISATION 


\section{THE ETHICAL \\ ORGANISATION}

\section{ETHICAL THEORY AND \\ CORPORATE BEHAVIOUR}

Alan Kitson and Robert Campbell

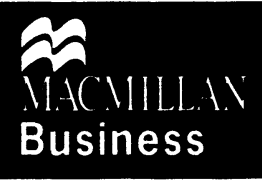


(C) Alan Kitson and Robert Campbell 1996

All rights reserved. No reproduction, copy or transmission of this publication may be made without written permission.

No paragraph of this publication may be reproduced, copied or transmitted save with written permission or in accordance with the provisions of the Copyright, Designs and Patents Act 1988, or under the terms of any licence permitting limited copying issued by the Copyright Licensing Agency, 90 Tottenham Court Road, London W1P 9HE.

Any person who does any unauthorised act in relation to this publication may be liable to criminal prosecution and civil claims for damages.

First published 1996 by

MACMILLAN PRESS LTD

Houndmills, Basingstoke, Hampshire RG21 6XS

and London

Companies and representatives

throughout the world

ISBN 978-0-333-62566-8 ISBN 978-1-349-24405-8 (eBook)

DOI 10.1007/978-1-349-24405-8

A catalogue record for this book is available from the British Library.

Copy-edited and typeset by Povey-Edmondson Okehampton and Rochdale, England

$\begin{array}{lllllll}10 & 9 & 8 & 7 & 6 & 5 & 4\end{array}$

$\begin{array}{lllll}05 & 04 & 03 & 02 & 01\end{array}$ 


\section{Contents}

Acknowledgements $\quad$ x

Notes on the Contributors $\quad \mathbf{x i}$

Introduction xiii

\section{PART I ORGANISATIONS AND ETHICS}

1 Business Ethics 3

1 Introduction 3

2 Ethics 17

$\begin{array}{ll}2.1 \text { Utilitarianism } & 7\end{array}$

2.2 Deontology 13

2.3 Virtue theory 15

Notes $\quad 18$

$\begin{array}{ll}\text { References } & 19\end{array}$

2 Case Studies in Business Ethics 21

1 The Use of Cases in the Study of Business Ethics 21

2 Aims of the Case Study Approach 22

3 Approaches to the Analysis of Cases 22

4 The Cases 25

References $\quad 26$

3 Virgin Atlantic and British Airways 27

1 Introduction 27

2 Background 28

3 The Story 31

4 The Consequences 32

5 Postscript 36 
References 37

Appendix 1 Chairman's Statement 38

Appendix 2 Shareholder Information and Directors' Interests 40

Appendix 3 Principal Investments 42

Appendix 4 BA's Code of Business Conduct 43

4 Queens Moat Houses Plc 45

1 Introduction 45

2 Tale of Two Valuers $\quad 47$

3 Department of Trade Investigation 47

4 Corporate Governance in Action 47

5 Debenture Holders and Capital Reorganisation 48

6 Past Dividend Payments and Shareholders' Interests 48

7 The New Management 49

References 49

Appendix 1 News Report Results for Year to 2 January $1994 \quad 50$

Appendix 2 Queens Moat House Plc Annual Report 1992

5 The Co-operative Bank 1

1 Introduction 63

2 Brief History of the Development of The Co-operative Bank 63

3 Evolution of Business Ethics in the Financial Services Sector 65

4 Development of Ethical Policy at The Co-operative Bank plc 66

5 Market Research 67

6 Ethical Audit of Existing Customer Relationships 69

7 The Bank's Ethical Policy 70

8 The Bank's Mission Statement 71

9 The Co-operative Bank plc - Trading Performance 1992/3 71

10 Institutionalisation of the Ethical Policy 73

11 Implementation of the Ethical Policy - A Vignette 74

References and Bibliography $\quad 80$

6 The Co-operative Bank $2 \quad 81$

1 Introduction $\quad 81$

2 Successful Ethics $\quad 81$

3 The Organisational Context $\quad 82$

4 The Research Findings $\quad 85$

$\begin{array}{ll}4.1 \text { Job content } & 85\end{array}$

4.2 How the ethical policy influences job performance 86

$\begin{array}{ll}4.3 \text { Incidents } & 87\end{array}$

4.4 Someone to turn to? $\quad 89$

4.5 Ensuring conformity $\quad 89$

4.6 The managers' personal views 90

4.7 Hypothetical circumstances 92 
5 Conclusions $\quad 93$

References $\quad 95$

Appendix 1 The Ethical Policy of The Co-operative Bank 95

Appendix 2 Questionnaire For Interviews With Managers 96

7 The Ethical Organisation $\quad 97$

1 Individuals and Organisations 97

2 Organisations are not Agents 98

3 Limited Liability 101

4 Society, Markets and Law 102

5 Characteristics of Ethical Organisations 104

6 Theories of Corporate Moral Excellence 105

7 Ethics and Stakeholder Theory 108

8 Ethics and Corporate Governance 111

Notes $\quad 116$

$\begin{array}{ll}\text { References } & 116\end{array}$

8 Corporate Codes and Ethics 118

1 Introduction 118

2 The Development of Codes of Ethics 120

3 Company Codes and Managerial Control 123

4 Who is being Protected by the Code? 125

5 Implementing Company Codes 126

6 Conclusion 130

Notes 131

$\begin{array}{ll}\text { References } & 131\end{array}$

9 Markets and Morality 133

1 Introduction 133

2 Neoclassical Economic Theory: Economic Man, Efficiency

3 Social Responsibilities of Business 138

4 Regulation and Self-Regulation $\quad 144$

5 Business and Government 148

6 International Business and Morality 150

7 Concluding Remarks 154

References $\quad 155$

\section{PART II MANAGEMENT AND ETHICS}

Introduction to Part II 158

10 Ethical Issues in Strategic Management 160

1 Introduction 160 
2 Significant Ethical Issues in Strategic Management

2.1 Setting the vision, aims and objectives

2.2 Leadership and senior managers' remuneration 162

2.3 Implementing strategic change 162

2.4 Changes in organisation ownership 163

2.5 Global strategic operations 164

3 Illustration: Strategic Visioning and Mission Statements 164

4 Principles Underlying an Ethical Approach to Strategic Management

4.1 Stakeholder theory, strategy and ethics 166

4.2 Loyalty and the psychological contract 166

4.3 Cultural relativism 167

5 Conclusion 168

Notes 168

$\begin{array}{ll}\text { Further Reading } & 169\end{array}$

$\begin{array}{ll}\text { References } & 170\end{array}$

11 Ethical Issues in Marketing $\quad 171$

1 Introduction 171

2 Marketers and Ethics 171

3 Empirical Evidence 173

4 Marketing Strategy $\quad 175$

5 Market Research 175

6 The Marketing Mix 176

7 Product 176

8 Price 177

9 Place 179

10 Promotion 180

11 People, Physical Evidence and Process 182

12 Conclusion 183

$\begin{array}{ll}\text { References } & 183\end{array}$

12 Ethical Issues in Purchasing 185

1 Introduction 185

2 Ethical Issues in Purchasing 186

3 Codes of Ethics 190

4 Vignettes 190

5 Ethical Principles in Purchasing 191

Further Reading 193

References $\quad 194$

13 Ethical Issues in Operations Management 195

1 Introduction 195

2 Definition of Operations Management 196 
3 Quality 199

4 Managerial Roles $\quad 200$

5 Examples of Ethical Problems 201

6 An Analytical Framework 201

7 Vignette 203

8 Guidelines for Ethical Decision-Making in Operations 206 $\begin{array}{ll}\text { Management } & 206 \\ \text { References and Bibliography } & 207\end{array}$

14 Ethical Issues in Human Resource Managements 208

1 Introduction 208

2 Vignette - Smallhouse School 211

3 Vignette - Tiphill County Council 213

4 Towards Ethical Recruitment and Selection 215

Appendix: Ethical Issues $\quad 218$

Further Reading $\quad 218$

$\begin{array}{ll}\text { References } & 219\end{array}$

15 Ethical Issues in Accounting 221

1 Introduction $\quad 221$

2 The Accounting Profession 221

3 Accountants - A Variety of Roles 222

4 The Rules Regulating the Professional Conduct of 223

5 Vignettes $\quad 225$

6 Discussion $\quad 227$

Notes $\quad 229$

References and Bibliography 229

16 Ethical Dilemas at Work 231

1 The Individual at Work 231

2 Power, Authority and Trust 232

3 Secrecy, Confidentiality and Loyalty 233

4 Resolving Dilemmas $\quad 235$

5 Advising Managers $\quad 237$

$\begin{array}{ll}\text { References } & 239\end{array}$

$\begin{array}{lr}\text { Bibliography } & 240\end{array}$

$\begin{array}{ll}\text { Index } & 251\end{array}$ 


\section{Acknowledgements}

This book is concerned with the problems raised by collaborative enterprise. Fortunately, few of the problems it discusses were faced in its actual production even though the book itself was also a collaborative enterprise. Because we realised early on the value of including material which focused on specific areas of management and actual cases, we also realised we would need to draw on contributions from specialists in those areas. We would like to take this opportunity to record the extent and nature of those contributions and also our thanks to those who made them:

Peter Taylor, Senior Lecturer in Accountancy, Bolton Business School, for Chapter 4

Trevor Williamson, Principal Lecturer in Financial Services, Manchester Metropolitan University, for Chapter 5

Dr M. Teresa Lunati, Senior Lecturer in Economics, Bolton Business School, for Chapter 9

Peter W.F. Davies, Lecturer in Strategic Management, Buckinghamshire College, for Chapter 10

Professor Greta Richards, Assistant Director, Newcastle Business School, and Collette Blanchfield, National Provincial Bank, Leeds, for Chapter 11

Graham Wood, Head of School of Business, University College Salford, for Chapter 12

Brian Elliott, Senior Lecturer in Operations Management, Bolton Business School, for Chapter 13

Wes Haydock, Senior Lecturer in Human Resources Management, Bolton Business School, for Chapter 14

Margaret Leigh, Lecturer in Accountancy, and Richard Schofield, Lecturer in Law, Bolton Business School, for Chapter 15.

ALAN KITSON ROBERT CAMPBELL 


\section{Notes on the Contributors}

Collette Blanchfield works for the National Provincial Bank in Leeds.

Peter W.F. Davies teaches strategic management and business ethics at Buckinghamshire College (a college of Brunel University). He is a member of COPE (Centre for Organisational and Professional Ethics), a joint Buckingham/Brunel venture. He graduated in mining engineering from Newcastle University in 1977, and worked for several years as a mining and production engineer. He took a master's degree in robotics and manufacturing automation at Imperial College.

Brian Elliott is Senior Lecturer in Operations Management at Bolton Business School. He gained management experience leading functional areas like productivity services, industrial relations and planning in several large manufacturing companies in both the textile and engineering sectors.

Wes Haydock is Principal Lecturer in Human Resource Management at Bolton Business School. He is course leader for the BA (Hons) business administration and teaches on a range of undergraduate and postgraduate courses, including an $\mathrm{MBA}$ and $\mathrm{MA}$ in human resource management. He obtained a BSc in industrial engineering from Hatfield Polytechnic in 1972 and an MSc in industrial relations and personal management from the London School of Economics in 1983. He worked in the electronics industry as a production manager and production control manager before entering the teaching profession. He current interests include management development, teamwork and general human resource management issues.

Margaret Leigh is Lecturer in Accounting at Bolton Business School. Her major research interests are concerned with the interface between law and accountancy.

M. Teresa Lunati is Senior Lecturer in Economics at Bolton Business School. She has also lectured at the University of Turin, Italy, and at the University of Wales, Aberystwyth. She holds a Laurea con Lode in Economia e Commercio from the University of Turin, an MA in economics from Essex University, and 
a DPhil in economics from the University of York. Her areas of interest include macroeconomic aspects of public finance (the macro effects of financing the public sector formed the topic for her doctoral thesis), the economic beliefs and behaviour of individuals, and ethical issues in economics (especially concerning altruism, co-operation, commitment and equity).

Greta Richards is Professor and Assistant Director at Newcastle Business School, University of Northumbria at Newcastle. A chartered psychologist, she has experience over many years of market research for products and services with consumers and industry, largely in the private sector, and twenty years as consultant for the Civil Service Commission in management recruitment and selection. She has designed and directed portfolios of undergraduate and postgraduate degree programmes in business and marketing and is an assessor in business and management for the Higher Education Funding Council for England.

Richard Schofield is a Lecturer in Law at Bolton Business School. His major research interest is in the area of organisational accountability, in particular systems of self-regulation.

Peter Taylor is Senior Lecturer in Accountancy and Finance at Bolton Business School. After qualifying as a chartered accountant he spent several years employed in the tourism industry as a financial accountant. He currently lectures in management accounting and taxation.

Trevor Williamson is Principal Lecturer in Financial Services at Manchester Metropolitan University. A graduate in management science from the University of Manchester Institute of Science and Technology, he was appointed course leader for the BA (Honours) financial services degree at Manchester Metropolitan University in January 1992. This followed over ten years of senior management experience working in finance houses and banking organisations. His latest position was Advance Controller at Girobank plc, responsible for control and development of the bank's commercial lending activities.

Graham Wood is Head of School of Business Studies at University College Salford. He graduated with a first-class honours degree in economics from University College Cardiff and also has an MA in business analysis from Lancaster University. His research interests are in marketing and purchasing ethics and he has published papers in the International Marketing Review and Business Ethics: A European Review. 


\section{Introduction}

Our reason for adding to the plethora of volumes on business ethics is that we hope we are contributing something new, something, moreover, that fills an important gap in what is currently available. The recent growth of interest in business ethics began in the US and the literature reflects this. We felt it was important to try to redress this balance by concentrating on European cases and the issues that matter in European business. We also wished to avoid the problems inherent in transposing discussions rooted in a very different business culture and legal system to the European context.

A problem in writing on business ethics is the risk of falling into one or another of two traps: of concentrating on theoretical (philosophical) material without grounding that material sufficiently in the real issues to which it should apply; or else of taking an overly pragmatic approach which ignores or minimises the theoretical difficulties such approaches should raise. We have tried to avoid both of these traps by placing at the heart of the book a sequence of case studies (Chapters 3, 4,5 and 6) and sharply focused surveys of areas of management practice (Chapters 10,11,12, 13, 14 and 15) and surrounding them with the theoretical material which is designed to supply both introduction and commentary. We hope we have thereby achieved an appropriate balance between theorising about business ethics and describing actual ethical problems.

It is not just a matter of balance, of course. There needs to be an integration of theory with practice and that presupposes a methodology to achieve it. We have adopted a position that owes a good deal to John Rawles (1972, p. 20f). ${ }^{1}$ A given ethical theory will have implications (obviously) about what is right and what wrong and these implications may or may not square with our moral intuitions ('gut feelings'). It would be naive to suppose that the first attempt to formulate a theory must be correct. But nor can we assume that our pre-theoretical moral feelings are defensible just as they stand. Rawles suggests that we should go through a process of reflectively considering how to adjust both our feelings and our theory until a stable balance is struck between them. He calls this position 'reflective equilibrium'. We do not claim 
to have achieved this here. But we do believe that the book provides material which will enable readers to achieve a 'reflective equilibrium' between their own instinctive reactions to the cases and vignettes we describe and a more considered, theoretically informed judgement. It is hopeless to suppose that theories can be formulated (or worse, taken off the philosophical shelf) in advance of considering the nature of the actual cases or problems to which they are meant to apply. But neither is it sensible to believe that simply working through cases, however thoroughly and assiduously, is enough to generate sufficent insight to generate realistic and principled responses to them. There is a halfway house which in our view is as bad as, or worse than, either of these, and this is to apply a limited number of simplified theoretical insights (usually loosely based on Kantianism and utilitarianism) and mechanically derive some stock conclusions which are often inconsistent with one another and which yield no insight into either the nature of the problems or of the merits and shortcomings of the theories themselves.

Quite apart from anything else, all of these ignore the question of how case studies are selected and formulated. What makes something a problem which is worth our attention? How much information is needed to convey what makes a situation problematic? What is important and significant in a case study and what inessential and incidental? Clearly without some kind of theoretical 'take' on an issue, none of these questions can be answered and examples, problems and case studies cannot even be put together. The belief that a pre-theoretical position is possible usually means that the most conservative view has prevailed and that, in itself, is something which ought to be questioned. Nonetheless, consideration of actual cases may lead one to wish to adjust the initial theoretical 'take' and then to reconsider the case in the light of that next move. Ultimately, what is being aimed at is a set of mutual adjustments which achieves the best possible 'fit' between example and theory.

Theory needs to be informed by actual cases in another sense, too. We need to be clear about what kinds of cases really are morally problematic for practitioners, and not just rely on theory to tell us what ought to be difficulties. We do not want to invent problems which are hardly ever confronted in practice but which are theoretically interesting, but nor do we want to swamp the reader with cases structured only by the most superficial or naive theoretical underpinnings. It has been our aim throughout to avoid both of these undesirable outcomes.

Finally, we hope that this volume will make a contribution through its stress on the importance of organisations to the study of business ethics. Whilst it is true that organisations are made up of people and that much depends on whether those people are equipped to make ethical decisions, to consider just those people and their decisons is to leave out something which is so important that, in its absence, the rest hardly makes any sense. Not only are organisations increasingly important influences on our lives, but most of 
us, for a significant portion of our lives, work within an organisation of one kind or another. Our ability to live an ethical life is profoundly affected by the ethics of the organisations with which we deal and within which we operate. For this reason we have chosen to focus on the extent to which it is possible for an organisation to be ethical and the impact that that will have on the actions of those who work for it.

Alan KITSON

ROBERT CAMPBELL

\section{Note}

1. Rawles, J. (1972) A Theory of Justice, Oxford University Press. 